\title{
ANALISIS KESALAHAN PENGGUNAAN PARTIKEL PADA MATA KULIAH SAKUBUN SHOCHUUKYUU MAHASISWA SEMESTER 3 PROGRAM STUDI PENDIDIKAN BAHASA JEPANG UNDIKSHA TAHUN AJARAN 2017/2018
}

\author{
M. Hodri ${ }^{1}$, I.W. Sadyana ${ }^{2}$, N.M.D.S. Mardani ${ }^{3}$ \\ Program Studi Pendidikan Bahasa Jepang, \\ Universitas Pendidikan Ganesha \\ Singaraja, Indonesia \\ e-mail: ohodblackburn@gmail.com \\ wayan.sadyana@undiksha.ac.id desak.mardani@undiksha.ac.id
}

\begin{abstract}
Abstrak
Penelitian ini bertujuan untuk menganalisis kesalahan partikel dalam karangan mahasiswa semester tiga jurusan Pendidikan Bahasa Jepang Undiksha. Penelitian ini menggunakan pendekatan deskriptif kualitatif dengan metode dokumentasi dalam pengumpulan data. Data dianalisis dengan metode analisis kesalahan berbahasa oleh Ellis (1987). Hasil penelitian menunjukkan bahwa bentuk kesalahan partikel yang dilakukan oleh pembelajar terdiri dari partikel no, ni, wa, ga, o, de, to, demo, e, dan mo. Kesalahan paling sering dilakukan adalah kesalahan partikel no yang berfungsi untuk menghubungkan nomina dengan nomina sebanyak 12 kesalahan. Kesalahan dikelompokkan dalam tiga tipe yaitu penghilangan (occusion), penambahan (addition), salah formasi (misformation). Kesalahan formasi (misformation) dan penghilangan (occusion) menjadi kesalahan yang paling banyak terjadi. Kesalahan disebabkan oleh Interferensi, penggunaan yang berlebihan (overgeneralization), pengambil alihan sistem bahasa yang tidak lengkap sehingga terjadi suatu penghilangan dalam suatu unsur bahasa (occusion), kegagalan memahami batasan dalam struktur bahasa target sehingga penggunaan partikel tidak sesuai dengan aturan yang benar (misformation).
\end{abstract}

Kata Kunci : Errors analysis, sakubun shochuukyuu, partikel.

\section{要旨}

本研究の目的はガネシャ教育大学日本語教育学科の作文初中級における助詞の誤用について 明らかにすることである。研究では記述の定性的が使うことであり、データはを学生書いた 作文から収集され、Ellis

の基づき助詞の誤用を分析した。結果、学習者による助詞の誤用は「の」、「に」、「は」 、「が」、「を」、「で」、「と」、「でも」、「へ」、「も」である。助詞の誤用が最も 多いのは「の」格助詞ことである。また助詞誤用のタイプから見ると削減助詞

(omission)、ミスフォーメーション助詞

(misformation) が最も多いことが分かった。助詞の誤用の要因は母語干渉、過度の一般化（overgeneralizati on）、不完全な応用する言語 (omission)、ミスフォーメーション助詞の誤用 (misformation)。 キーワード : 助詞の誤用、作文初中級、助詞

\section{Pendahuluan}

Mata kuliah mengarang (sakubun) merupakan salah satu mata kuliah yang ada di Jurusan Pendidikan Bahasa Jepang UNDIKSHA. Pada mata kuliah mengarang dituntut untuk mengaplikasikan keterampilan menulis ketika akan menyampaikan suatu ide atau gagasannya kedalam sebuah karangan. Sutedi (2009) berpendapat bahwa dalam berkomunikasi secara tertulis, jika seseorang bertindak sebagai pemberi informasi diperlukan keterampilan menulis huruf, kosakata, frase, dan kalimat dengan benar sesuai dengan aturan gramatika yang berlaku. Artinya dalam mengarang, mahasiswa harus memiliki kemampuan menulis huruf kana dan kanji, pengorganisasian kalimat, penguasaan 
gramatikal dan kesinambungan makna serta ungkapan-ungkapan tertentu dalam bahasa Jepang supaya menjadi kalimat yang baik dan sesuai dengan aturan gramatika.

Gramatika merupakan aturan-aturan umum yang digunakan untuk mengatur satuansatuan kecil suatu bahasa yang tersusun sistematis dalam suatu bahasa tertentu (Hayashi dalam Sudjianto dan Dahidi, 2014). Dalam bahasa tulisan hal yang kecil seperti partikel tidak dapat dihilangkan atau dillesapkan karena dapat menjadikan kalimat mempunyai arti dan makna yang berbeda serta kalimat tidak dapat dipahami maksudnya. Akan tetapi dalam bahasa lisan, partikel sering dihilangkan dalam suatu kalimat terutama dalam kalimat percakapan. Akibatnya, hal tersebut sering menimbulkan keraguan tentang pentingnya mempelajari partikel itu sendiri (Sudjianto, 2000:6). Untuk mengetahui urgensi partikel dalam kalimat, perhatikan contoh kalimat dalam karangan mahasiswa berikut.

\section{Contoh 1}

よるのろくじにわたしはホテルをもどりました。

Yoru no roku ji ni watashi wa hoteru o modorimashita.

\section{Contoh 2}

Tanah Lot はタバナンがあります。

Tanah Lot wa tabanan ga arimasu

Contoh (1) dan (2) diatas merupakan contoh penggunaan partikel yang kurang tepat. Pada contoh (1), penggunaan partikel o setelah nomina hoteru pada kalimat tersebut kurang tepat. Pertikel o memang memiliki fungsi yang sama dengan partikel ni untuk menyatakan arah, akan tetapi pada konteks kalimat diatas penggunaan partikel o kurang tepat karena partikel o bukan untuk menyatakan arah dan seharusnya partikel o diganti partikel ni yang menyatakan tempat pulang atau kembali (Sudjianto, 2000). Kemudian pada contoh (2), penggunanan partikel ga setelah kata Tabanan kurang tepat. Tabanan merupakan kata keterangan yang menunjukkan tempat (daerah) dari salah satu objek wisata yaitu Tanah Lot. Partikel ga yang diikuti kata arimasu menunjukkan keberadaan akan sesuatu dan pengalaman terhadap sesuatu bukan menunjukkan tempat beradanya sesuatu seperti tempat, seseorang, binatang dan lain sebagainya. Dilihat dari kalimat pada contoh (2), penggunaan partikel ga diatas tidak tepat karena yang seharusnya digunakan adalah partikel ni yang menyatakan tempat beradanya sesuatu (Chandra, 2009).

Kalimat pada contoh (1) dan (2) merupakan salah satu contoh kesalahan pada pengguanaan partikel yang terdapat dalam karangan mahasiswa. Contoh-contoh diatas merupakan kesalahan yang terjadi pada karangan bahasa Jepang yang dapat menimbulkan masalah dalam pembelajaran bahasa Jepang jika tidak segera ditanggulangi. Kesalahan merupakan bagian dari proses belajar itu sendiri. Kesalahan dapat mengganggu pencapaian tujuan pengajaran bahasa, bahkan dikatakan bahwa kesalahan berbahasa yang terjadi menandakan suatu pembelajaran yang tidak berhasil atau gagal (Tarigan dan Tarigan, 1995). Oleh karena itu yang perlu dilakukan adalah bukan menghindar dari kesalahan, tetapi justru harus menghadapi dan memperbaiki kesalahan berbahasa sehingga diharapkan dapat meminimalisir atau bahkan menghapuskan kesalahan yang sama supaya tidak terjadi dimasa yang akan datang.

Untuk meminimalisir atau menghapuskan kesalahan diperlukan analisis kesalahan untuk mengetahui penyebab kesalahan berbahasa. Salah satu studi yang membahas masalah kesalahan adalah analisis kesahalahan berbahasa (AKB). Analisis kesalahan berbahasa merupakan suatu "proses". Sebagai suatu proses, maka ada prosedur yang harus dituruti selaku pedoman kerja (Tarigan, 2011). Analisis kesalahan dalam kaitannya dengan pengajaran bahasa sangat fungsional baik dalam pengajaran B1 ataupun pengajaran B2 (Tarigan dan Tarigan, 1995). Analisis kesalahan berbahasa, sebagai prosedur kerja memiliki langkah-langkah yang digunakan para peneliti dan guru bahasa yang 
meliputi pengumpulan sample, identifikasi kesalahan yang terdapat dalam sample, penjelasan kesalahan, mengklasifikasikan kesalahan itu berdasarkan penyebabnya, serta tahap evaluasi atau penilaian taraf keseriusan kesalahan (Ellis dalam Tarigan dan Tarigan, 1995).

Kesalahan dalam berbahasa merupakan hal yang normal yang pasti dilakukan oleh semua pelajar terutama bagi pemula. Dari kesalahan yang dilakukan oleh pembelajar, maka selanjutnya dilakukan analisis sehingga didapat keuntungan yaitu mengetahui penyebab kesalahan, kemudian dari kesalahan tersebut diberikan contoh perbaikan dan diharapkan dapat menghindari kesalahan yang sama terulang lagi dimasa yang akan datang.

\section{Metode}

Penelitian ini merupakan penelitian deskriptif dengan pendekatan kualitatif. Pendekatan kualitatif digunakan untuk mendeskripsikan kesalahan partikel yang dilakukan oleh mahasiswa. Dalam penelitian ini akan dideskripsikan bentuk atau jenis kesalahan partikel dan tipe-tipe kesalahan yang terdapat dalam karangan serta faktor penyebab terjadinya kesalahan. Metode yang digunakan dalam penelitian ini adalah metode dokumentasi yaitu berupa karangan pada mata kuliah sakubun. Selanjutnya dalam menganalisis data digunakan metode studi kasus untuk menganalis suatu masalah secara mendalam. Maka dari itu, studi kasus digunakan untuk menganalis bagaimana kesalahankesalahan pada penggunaan partikel beserta faktor yang terkait dalam karangan. Data berupa kalimat dalam karangan yang sudah dikumpulkan selanjutnya akan dianalisis. Setelah semua kesalahan pada penggunaan partikel ditemukan dan dikelompokkan, kemudian akan ditandai atau diberikan kode untuk mempermudah proses analisis data. Setelah data diberikan tanda, kemudian selanjutnya dianalisis dan diuraikan kesalahankesalahan pada penggunaan partikel dalam karangan. Dalam analisis data, akan diuraikan tipe-tipe kesalahan yaitu Penghilangan (omission), penambahan (addition), salah formasi (misformation), salah susun (misordering) yang disertai pula perbaikan dari kesalahan dan penyebab terjadinya kesalahan. Setelah selesai, dari ketegori kesalahan tersebut akan dihitung jumlah kesalahan pada setiap tipe kesalahan untuk mengetahui kesalahan yang paling banyak atau sering terjadi dalam karangan.

\section{Hasil dan Pembahasan}

Dalam karangan mahasiswa ditemukan kesalahan seperti penghilangan (omission) sebanyak 25 kesalahan, penambahan (addition) sebanyak 8 kesalahan, salah formasi (misformation) sebanyak 33 kesalahan, salah susun (misordering) sebanyak 8 kesalahan yang terbagi kedalam kesalahan partikel No, Ni, Wa, Ga, O, De, To, Demo, E, Mo, Kara, No Wa. Selanjutnya, dalam pemaparan hasil akan dianalisis kesalahan partikel dalam kalimat berdasarkan jenis partikel serta penyebab terjadinya kesalahan partikel dalam karangan.

1. Kesalahan Partikel No (の)

\section{Data 2}

いちばんの有名な食べ物はチョコレートケーキです。

/lchiban no yuumei na tabemono wa chokoreeto keeki desu/.

Kalimat 2 merupakan kalimat yang mengalami kesalahan karena penambahan partikel yang tidak tepat dalam kalimat. Dalam kalimat, terjadi kesalahan karena menambahkan partikel no setelah kata ichiban. Dalam kalimat diatas terdiri Ichiban (Adv) + no (partikel) + yuumei (KS) + wa (partikel) + chokoreeto keeki (KB) + desu (Copula). Kata ichiban termasuk dalam kelas kata fukushi (adverbia) yang berfungsi untuk menerangkan verba, adjektifa dan adverbia lainnya serta digunakan untuk menyatakan derajat suatu aktifitas, suasana atau perasaan pembicara (Sudjianto dan Dahidi, 2004). Dalam kalimat diatas, penambahan partikel no setelah kata ichiban tidak tepat karena kata ichiban tidak perlu ditambahkan partikel setelahnya sehingga harus dihilangkan karena tidak sesuai dengan aturan gramatika dalam bahasa Jepang yang benar. Kalimat yang benar adalah 
いちばん有名な食べ物はチョコレートケーキです。

/lchiban yuumei na tabemono wa chokoreeto keeki desu/

Dengan menghilangkan partikel no setelah kata ichiban (Adv) maka kalimat tersebut akan sesuai dengan aturan gramatika yang benar dalam pola $A$ wa $B$ desu .

\section{Partikel Ni (に)}

Data 4

7 月 10 日バリへ帰りました。

/shichi gatsu tooka bari e kaerimashita/

Kesalahan dalam kalimat 4 adalah terdapatnya penghilangan partikel ni setelah shichi gatsu tooka. Shichi gatsu tooka merupakan kata katerangan (Kk waktu) dalam kalimat, Bari merupakan objek $(\mathrm{O})$ dan kaerimashita merupakan predikat $(\mathrm{P})$. Kalimat diatas tersusun dengan shichi gatsu tooka (Kk waktu) + bari $(\mathrm{O})$ + e (partikel) + kaeru (Predikat). Sesuai dengan aturan gramatika yang benar, sebagai penanda waktu dilakukannya suatu aktifitas seperti tanggal, bulan, tahun dalam bahasa Jepang, perlu ditambahkan partikel ni setelah kata tersebut (Sudjianto, 2000). Sehingga dalam hal ini, setelah kata shichigatsu tooka dalam kalimat diatas perlu ditambahkan partikel ni sebagai penanda waktu dilakukannya suatu aktifitas.

7 月 10 日にバリへ帰りました。

/shichi gatsu tooka ni bari e kaerimashita/

Dengan menambahkan partikel ni setelah kata shichi gatsu tooka (Kk waktu) maka akan diketahui bahwa kata tersebut merupakan keterangan waktu dan penambahan partikel ni sesuai dengan aturan gramatika yang benar.

\section{3. $\quad$ Partikel Wa (は) \\ Data 8 \\ かメラは写真を撮る。}

/kamera wa shashin o toru/

Dalam kalimat 8, terdapat kesalahan penggunaan (misformation) partikel wa setelah nomina kamera. Dalam kalimat terdiri dari kamera (Kk alat) + wa (partikel) + shashin $(\mathrm{O})+0$ (partikel) + toru $(\mathrm{P})$. Kamera merupakan suatu alat yang digunakan ketika akan berfoto. Kesalahan yang terjadi pada kalimat diatas adalah karena penggunaan partikel wa setelah kata kamera karena partikel wa tidak mempunyai fungsi untuk menyatakan suatu cara atau alat yang digunakan pada waktu melakukan suatu aktifitas. Sesuai dengan aturan gramatika dalam bahasa Jepang, partikel yang mempunyai fungsi untuk menunjukkan suatu alat yang digunakan pada waktu melakukan suatu aktifitas adalah partikel de (Sudjianto, 2000). Pada kalimat tersebut, partikel wa harus diganti dengan partikel de yang mempunyai fungsi tersebut. Penggunaan partikel wa dalam kalimat yang tidak tepat sehingga menjadikan kalimat tidak dapat dipahami maksudnya. Kalimat yang benar adalah

かメラで写真を撮る。

/kamera de shashin o toru/

Setelah mengganti partikel wa dengan partikel de maka kalimat tersebut dapat dipahami dengan baik dan sesuai dengan aturan gramatika yang benar yaitu kamera (Kk alat) + de (Partikel).

4. Partikel Ga (が)

Data 9

お金で食べ物が買います。

lokane de tabemono ga kaimasu/ 
Dalam kalimat 8 ini terdapat kesalahan penggunaan (missformation) partikel ga setelah nomina tabemono. Kalimat terdiri dari kata okane (Kk alat) + tabemono $(\mathrm{O})+\mathrm{Ga}($ partikel) + kaimasu $(P)$. Dalam kalimat tersebut, terdapat kesalahan dalam penggunaan partikel ga setelah kata tabemono yang merupakan objek kalimat. Partikel ga memang mempunyai fungsi sebagai penanda objek dalam kalimat, akan tetapi dalam kalimat ini penggunaan partikel ga tidak tepat karena partikel ga tidak dapat ditambahkan setelah nomina yang diikuti kata verba aktifitas. Sehingga setelah kata tabemono yang merupakan objek dalam kalimat, dalam aturan gramatika yang benar, partikel yang tepat adalah partikel o karena partikel o mempunyai fungsi sebagai penanda objek dalam kalimat yang dikuti verba aktifitas kaimasu (Sudjianto, 2000). Adapun kalimat perbaikan yang benar adalah

お金で食べ物を買います。

lokane de tabemono o kaimasu/

Dengan mengganti partikel ga dengan partikel o maka kalimat tersebut dapat dipahami dengan baik dan sesuai dengan aturan gramatika yang benar yaitu nomina tabemono $(\mathrm{O})+$ de (Partikel).

\author{
5. Partikel O (を) \\ Data 11 \\ あそこで私たちを買い物してから、ホテルへ帰りました。 \\ /asoko de watashitachi o kaimonoshite kara, hoteru e kaerimashita/
}

Kalimat 11 merupakan kalimat yang berisi kesalahan penggunaan (misformation) partikel o setelah kata watashitachi. Kalimat terdiri dari kata Asoko de (NP + partikel) + watashitachi o (NP + Partikel) + kaimonoshitekara (VP + pola kalimat) + hoteru e (NP + partikel) + kaerimshita (VP). Kata watashitachi adalah subjek yang diikuti partikel o dalam kalimat diatas. Partikel o merupakan partikel yang tidak mempunyai fungsi sebagai penanda subjek dalam kalimat sehingga penggunaan partikel o setelah kata watashitachi tidak tepat. Sesuai dengan aturan gramatika yang benar, partikel o seharusnya diganti dengan partikel yang mempunyai fungsi sebagai penanda subjek dalam kalimat yaitu partikel wa atau partikel ga (Chandra, 2009). Penggunaan partikel o yang salah dalam kalimat menyebabkan kalimat tidak dapat dipahami sehingga perbaikan yang tepat adalah

あそこで私たちは買い物してから、ホテルへ帰りました。

lasoko de watashitachi wa kaimonoshite kara, hoteru e kaerimashita

Penggunaan partikel o setelah kata watashitachi (NP) akan menandakan bahwa watashitachi merupakan objek dari verba kaimonosuru (VP) sehingga kalimat akan menjadi aneh dan tidak sesuai dengan aturan gramatika yang benar yaitu watashitachi (S) + wa (partikel) kaimonoshite (VP bentuk te + kara).

\title{
6. Partikel De (で)
}

Data 13

先月、私は友達と一緒にデンパサルで日本のレストランへ行きました。 ikimashita/

/sengetsu, watashi wa tomodachi to isshoni denpasaru de nihon no resutoran e

Kesalahan dalam kalimat 13 adalah kesalahan penggunaan (misformation) partikel de. Kalimat diatas merupakan kalimat yang memiliki pola gramatika Kk (waktu) + A wa + B + to isshoni + Kk (tempat) + e + Verba. Kata denpasaru (NP), Nihon (NP) dan resutoran (NP) merupakan nomina yang menerangkan tempat dilakukannya aktifitas sehingga dalam hal ini, sesuai dengan aturan gramatika yang benar, untuk menunjukkan tempat berlangsungnya aktifitas maka ditandai dengan penggunaan partikel e setelah kata tersebut (Sudjianto, 
2000). Denpasar merupakan nama kota yang didalamnya terdapat restoran yang menyajikan masakan Jepang. Dalam pola seperti diatas, ketiga nomina (NP) tersebut merupakan kata yang memerlukan partikel sebagai penghubung supaya menjadi suatu kesatuan makna. Partikel yang sesuai dengan hal tersebut adalah partikel no bukan partikel de karena partikel no mempunyai fungsi untuk menggabungkan beberapa nomina supaya menjadi suatu kesatuan makna (Sudjianto, 2000). Kalimat perbaikan yang benar adalah

先月、私は友達と一緒にデンパサルの日本のレストランへ行きました。

/sengetsu, watashi wa tomodachi to isshoni denpasaru ni nihon no resutoran $\mathrm{e}$ ikimashita/

Setelah mengganti partikel de dengan partikel no maka ketiga nomina denpasaru (NP) + no + nihon (NP) + no + resutoran (NP) akan menjadi suatu kesatuan makna dan menjadi kata keterangan (Kk tempat).

\section{Partikel To (と)}

Data 14

友達と連絡したいからです。

/tomodachi to renrakushitai kara desu/

Kesalahan dalam kalimat 14 merupakan kesalahan penggunaan (misformation) partikel to. Kalimat diatas terdiri dari kata tomodachi $(O)+$ to (partikel) + renrakushitai $(P)+$ kara (partikel) + desu (Copula). Kata tomodachi dalam kalimat diatas merupakan objek yang dituju subjek dalam kalimat. Penggunaan partikel to setelah kata tomodachi tidak tepat karena untuk menunjukkan objek dalam kalimat, partikel yang tepat adalah partikel ni atau partikel o (Chandra, 2009). Penggunaan partikel to yang salah dalam kalimat diatas membuat kalimat tidak dapat dipahami dengan baik sehingga partikel to harus diganti dengan partikel ni atau partikel o. Kalimat perbaikan yang tepat dari kalimat diatas adalah

友達に/を連絡したいからです。

/tomodachi ni / o renrakushitai kara desu/

Setelah mengganti partikel to dengan partikel ni atau o maka sesuai dengan aturan gramatik yang benar yaitu tomodachi sebagai objek hidup (NP) + ni atau o (Partikel).

8. Partikel Demo (でも)

Data 15

食べ物は美味しいですが、でも值段は高いです。

/tabemono wa oishii desu ga, demo nedan wa takai desu/

Dalam kalimat 15, terdapat kesalahan penambahan partikel yang tidak perlu ditambahkan dalam kalimat. Kalimat diatas merupakan kalimat yang berpola tabemono (KB) + wa + oishii (KS) + desu + ga + demo + nedan (KB) + wa + takai (KS) + desu. Penambahan partikel demo setelah partikel ga dalam kalimat diatas tidak sesuai dengan pola aturan gramatika yang benar A + wa + B desu + ga + C + wa + D desu (3A CORPORATION, 2008). Penambahan partikel demo membuat kalimat tidak dapat dipahami maksudnya. Karena kalimat diatas merupakan jenis kalimat yang berlawanan atau bertolak belakang, maka ditandai dengan keberadaan partikel demo atau ga dalam bahasa Jepang. Penambahan partikel demo dalam kalimat tersebut tidak tepat karena sebelum partikel demo sudah menggunakan partikel ga untuk menunjukkan bahwa bagian kalimatnya mempunyai hubungan yang berlawanan atau bertolak belakang (Sudjianto, 2000). Sehingga dalam kalimat tersebut partikel demo harus dihilangkan agar kalimat dapat dipahami serta sesuai dengan aturan gramatika bahasa Jepang yang benar. Kalimat perbaikan yang benar adalah

食べ物は美味しいですが、值段は高いです。

/tabemono wa oishii desu ga, nedan wa takai desu/ 
Dengan menghilangkan partikel demo maka kalimat akan sesuai dengan pola $\mathrm{A}+\mathrm{wa}+$ B desu + ga + C + wa + D desu .

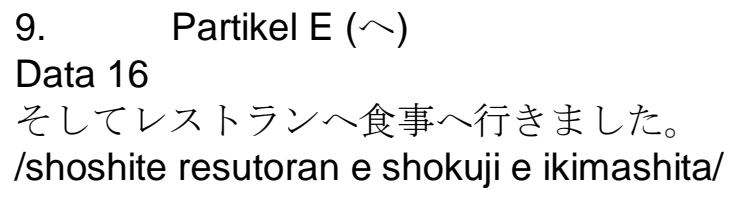

Kesalahan dalam kalimat 16 merupakan kesalahan dalam penggunaan (misformation) partikel. Kalimat terdiri dari kata soshite (konjungsi) + resutoran e (NP + partikel ) + shokuji e $(\mathrm{NP}+$ partikel) + ikimashita (VP). Dapat dilihat dalam kalimart diatas terdapat dua partikel yang sama dalam kalimat yaitu partikel e. Penggunaan partikel e setelah kata resutoran menandakan arah atau jurusan yang dituju yang berhubungan dengan tempat (Sudjianto, 2000).

Kemudian penggunaan partikel e setelah kata shokuji dalam kalimat diatas tidak tepat karena kata shokuji merupakan nomina yang menjadi tujuan dilakukannya suatu kegiatan. Partikel e tidak mempunyai fungsi tersebut sehingga harus digantikkan partikel ni yang mempunyai fungsi untuk menyatakan tujuan dilakukannya suatu kegiatan (Chandra, 2009). Partikel e dan partikel ni dapat saling menggantikan satu sama lain apabila digunakan untuk menunjukkan tempat tujuan, tempat kembali, tempat kedatangan dari suatu kegiatan. Akan tetapi dalam kalimat ini, partikel e tidak tepat dan harus diganti dengan partikel ni supaya kalimat dapat dipahami dengan baik. Kalimat perbaikan yang benar adalah

そしてレストランへ食事に行きました。

/shoshite resutoran e shokuji ni ikimashita/

10. Partikel Mo (も)

Data 17

色々な日本の食べ物もがたくさんあります。/iroiro na nihon no tabemono mo ga takusan arimasu/

Terjadi kesalahan penambahan parikel mo yang tidak tepat dalam kalimat 17. Kata Nihon no tabemono (NP + partikel + NP) merupakan objek dalam kalimat. Kata Nihon no tabemono diikuti oleh dua partikel mo dan ga. Dalam hal ini terdapat panambahan partikel yang tidak tepat dalam kalimat diatas. Partikel mo menandakan adanya keterkaiatan makna dengan kata atau kalimat sebelumnya sedangkan partikel ga berfungsi sebagai penanda objek yang diikuti oleh pola arimasu (Sudjianto, 2000). Kesalahan penambahan yang terjadi adalah kesalahan dalam menambahkan partikel mo disebabkan karena kalimat diatas tidak mempunyai hubungan keterkaitan dengan kalimat sebelumnya dalam karangan. Penggunaan partikel mo dalam kalimat tersebut tidak tepat dan menjadikan kalimat tidak dapat dipahami maksudnya sehingga penggunaan partikel ga lebih tepat dan partikel mo dihilangkan. Kalimat perbaikan yang benar adalah

色々な日本の食べ物もがたくさんあります。

/iroiro na nihon no tabemono ga takusan arimasu/

11. Partikel Kara (から)

Data 19

マンガが大好きですから。

/Manga ga daisuki desu kara/

Kesalahan dalam kalimat 19 merupakan kesalahan dalam menyusun partikel kara. Penempatan partikel kara dalam kalimat tersebut tidak sesuai dengan aturan gramatika dalam bahasa Jepang yaitu partikel kara dalam kelompok setsuzokujoshi dengan pola $\mathrm{O}+$ partikel + VP + kara (partikel) + desu (copula) (Sudjianto, 2000). Partikel kara digunakan untuk menunjukkan bahwa kalimat sebelumnya adalah penyebab atau alasan terjadinya suatu hal (Sudjianto, 2000). Pada fungsi ini partikel kara biasanya terletak diakhir kalimat dan diikuti kopula desu. Akan tetapi dalam kalimat 19, partikel kara terletak setelah kopula desu. Maka dari itu kalimat diatas tidak tepat karena terjadi kesalahan dalam menempatkan 
partikel kara yang seharusnya berada didepan copula desu. Perbaikan dari kalimat diatas adalah

$$
\text { マンガが大好きからです。 }
$$

/Manga ga daisuki kara desu/

Dengan menempatkan partikel kara sebelum copula desu (kara + desu) maka kalimat tersebut sesuai dngan aturan gramatika yang benar.

Faktor Penyebab

Dari analisis yang dilakukan pada kesalahan-kesalahan yang terdapat dalam karangan, penyebab dari kesalahan yang dilakukan oleh pembelajar yaitu sesuai dengan pendapat Schuman dan Stensen (dalam Hasyim, 2002) dan studi Tenges (dalam Hasyim, 2002), kesalahan terjadi karena kesalahan kinerja dalam penyelesaian yang diakibatkan oleh keterbatasan memori, kesalahan karena interferensi yang menunjukkan kegagalan belajar dalam membedakan sistem bahasa ibu dan bahasa target, serta karena pengambil alihan tata bahasa target yang tidak lengkap sehingga terjadi kesalahan seperti penghilangan (occusion), penambahan (addition), salah formasi (misformation) dan salah susun (misordering) terhadap unsur-unsur kalimat seperti penghilangan partikel yang seharusnya ada dalam kalimat, penambahan partikel yang tidak sesuai, kesalahan penggunaan (misformation) partikel yang tidak tepat serta kesalahan dalam menyusun partikel yang sesuai dengan aturan gramatika bahasa Jepang yang benar.

Selain itu, perbedaan antara sistem gramatika bahasa Jepang dan bahasa Indonesia membuat pembelajar kesulitan sehingga yang terjadi adalah penggunaan sistem bahasa pertama yaitu bahasa Indonesia kedalam sistem bahasa yang sedang dipelajari (bahasa Jepang) untuk memudahkan dalam membuat kalimat. Hal ini sesuai dengan pendapat Sutedi (2009) tentang perbedaan antara sistem B1 dan B2 menyebabkan kesulitan dan persamaannya akan memudahkan dalam mempelajari bahasa target (B2) tersebut. Sehingga dari perbedaan tersebut pembelajar cenderung melakukan kesalahan terutama kesalahan partikel seperti kesalahan penghilangan, penambahan, salah formasi dan salah susun.

Kemudian kesalahan juga disebabkan karena strategi komunikasi sesuai dengan pendapat Brown (dalam Hasyim, 2002) yaitu ketika ingin menyampaikan pesan dalam berkomunikasi, pembelajar menggunakan beberapa teknik seperti pembuatan kata baru, pemakaian kata yang terlalu banyak dan tidak perlu, dan pembuatan pola baru yang tanpa disadari bahwa semua itu merupakan sumber kesalahan. Dalam hal ini kecenderungan pembelajar adalah menambahkan partikel yang tidak perlu kedalam kalimat (addition), salah dalam memformasikan partikel (misformation) serta salah dalam menyusun partikel (misordering) yang sesuai dengan aturan gramatika dalam bahasa Jepang yang benar.

Dari keseluruhan jumlah data yakni sebanyak 74 data kesalahan partikel, dianalisis 25 data yang mewakili semua data kesalahan partikel yaitu terdiri atas kesalahan partikel No, $\mathrm{Ni}, \mathrm{Wa}, \mathrm{Ga}, \mathrm{O}$, De, To, Demo, E, Mo, Kara. Kesalahan-kesalahan partikel yang terdapat dalam karangan dikelompokkan kedalam empat tipe kesalahan yaitu penghilangan (occusion), penambahan (addition), salah formasi (misformation) dan salah susun (misordering). Kesalahan formasi (misformation) dan penghilangan (occusion) menjadi kesalahan yang sering dilakukan oleh pembelajar sedangkan kesalahan penambahan (addition) dan penyusunan (occusion) partikel sedikit terjadi dalam karangan.

Faktor penyebab terjadinya kesalahan dalam karangan mahasiswa adalah Interferensi, Overgeneralization yaitu penyimpangan dari struktur bahasa pada umumnya atau berlebihan dalam mengaplikasikan kaidah bahasa (addition), pengambil alihan sistem bahasa yang tidak lengkap sehingga terjadi suatu penghilangan dalam suatu unsur bahasa (occusion), kegagalan memahami batasan dalam struktur bahasa target sehingga menggunakan partikel dalam konteks tidak sesuai dengan aturan yang benar (misformation).

\section{Simpulan dan Saran}

A. Simpulan 
Bentuk-bentuk kesalahan yang terjadi dalam karangan mahasiswa Jurusan Pendidikan Bahasa Jepang UNDIKSHA terdiri atas kesalahan partikel No, Ni, Wa, Ga, O, De, To, Demo, $\mathrm{E}$, Mo, Kara. Kesalahan-kesalahan partikel yang terdapat dalam karangan dikelompokkan kedalam tiga tipe kesalahan yaitu penghilangan (occusion), penambahan (addition), salah formasi (misformation). Kesalahan formasi (misformation) dan penghilangan (occusion) menjadi kesalahan yang sering dilakukan oleh pembelajar sedangkan kesalahan penambahan (addition) dan penyusunan (occusion) partikel sedikit terjadi dalam karangan.

Faktor penyebab terjadinya kesalahan dalam karangan mahasiswa adalah Interferensi, Overgeneralization yaitu penyimpangan dari struktur bahasa pada umumnya atau berlebihan dalam mengaplikasikan kaidah bahasa (addition), pengambil alihan sistem bahasa yang tidak lengkap sehingga terjadi suatu penghilangan dalam suatu unsur bahasa (occusion), kegagalan memahami batasan dalam struktur bahasa target sehingga menggunakan partikel dalam konteks tidak sesuai dengan aturan yang benar (misformation).

\section{B. Saran}

Dalam penelitian ini disadari bahwa terdapat beberapa kekurangan sehingga disarankan : Untuk peneliti selanjutnya apabila ingin meneliti tentang kesalahan dalam karangan, perhatikan ketika mengklasifikasikan data supaya tidak melakukan kesalahan dalam menentukan objek penelitian dan apabila ingin meneliti tentang partikel saja sebaiknya lebih dikhususkan pada partikel yang menjadi masalah utama dalam pembelajaran.

\section{Daftar Pustaka}

Bhela, Beljit.(1999)."Native Language Interference In Learning A Second Language: Exploratory Case Study Of Native Language Interference With Target Language Usage". International Education Journal, Volume 1, Nomer 1 (hlm 22-31).

Chandra, T.2009.Nihongo No Joshi.cetakan ke 2. Jakarta: Evergreen.

Harisal. 2015. Analisis Kesalahan Dalam Karangan Bahasa Jepang Mahasiswa Sastra Jepang Universitas Hasanuddin. Tesis (diterbitkan). Program Pascasarjana Linguistik, UNHAS Makassar.

Hasyim, Sunardi. (2002). "Error Analysis In the Teaching of English". Volume 4, Number 1 (hal. 42-50).

Lekova, B.(2010). "Language Interference and Methods Of ITS Overcoming In Foreign Language Teaching". Trakia Journal of Sciences, Volume 8, Suppl.3,210 (hlm. 320324).

Marion, E.C.(2008). "Analisis Kesalahan Partikel Ni dan De". Lingua Cultura, Volume 2, Nomor 1 (hlm.46-58).

Novianti, W.D.(2016). "Analisis Kesalahan Penggunaan Partikel De, Ni dan O pada Kalimat Pembelajar Bahasa Jepang". Japanese Literature, Volume 2, Nomor 2 (hlm.1-8).

Nurhadi, didik.(2017). "Struktur Teks Karangan Bahasa Jepang: Analisis Pada Karangan Mahasiswa Angkatan 2013". Paramasastra,Volume 4, Nomor 1 (hlm.72-79).

Parera, Daniel. 1986. Linguistik Edukasional. Jakarta: Erlangga.

Sudjianto.2000.Gramatika Bahasa Jepang Modern. Cetakan ke 1. Bekasi: Kesaint Blanc.

Sudjianto dan Ahmad Dahidi. 2014. Pengantar Linguistik Bahasa Jepang. Jakarta: Kesaint Blanc.

Sutedi, Dedi. 2009. Penelitian Pendidikan Bahasa Jepang. Bandung: Humaniora.

Tarigan, Henry Guntur. 2011. Pengajaran Pemerolehan Bahasa. Bandung: Angkasa. 
Tarigan, Henry Guntur dan Djago Tarigan. 1995. Pengajaran Analisis Kesalahan Berbahasa. Cetakan ke 10. Bandung: Angkasa.

Wahyuddin, Zida.(2012). “Analisis Kesalahan Berbahasa Dalam Tugas Sakubun”. Parafrase, Volume 12, Nomor 2 (hlm. 28-33).

Wedayanti, N. P. L.(2016). "Interferensi Bahasa Indonesia Dalam Bahasa Jepang". Jurnal Kotoba, Volume 13, Edisi Khusus (hlm. 1-13).

3A Corporation. 2006. Minna No Nihongo II. Surabaya: IMAF press 